\title{
Pastel Tutup Daging Ayam dan Daun Kelor sebagai Pemberian Makanan Tambahan Balita Stunting di Puskesmas Dinoyo Kota Malang: Kajian Nilai Gizi, Mutu Protein dan Daya Terima
}

\section{Fitria Kurniawati* dan I Nengah Tanu Komalyna}

Jurusan Gizi, Politeknik Kesehatan Kemenkes Malang, Malang, Indonesia

Diterima: 28 Desember 2020; Disetujui: 23 Maret 2021

\begin{abstract}
Abstrak
Stunting merupakan kurangnya energi dan protein dalam jangka waktu yang lama ditandai tinggi badan menurut umur. Pemberian Makanan Tambahan (PMT) pastel tutup daging ayam dan daun kelor diharapkan mampu untuk menangani stunting. Penelitian ini bertujuan untuk mengkaji karakteristik nilai gizi, mutu protein dan daya terima dari Pastel Tutup sebagai alternatif pangan fungsional dalam bentuk PMT. Desain menggunakan Rancangan Acak Lengkap. Subjek yang digunakan 15 panelis agak terlatih yaitu 15 pegawai Puskesmas Dinoyo untuk menguji organoleptik PMT pastel tutup. Teknik pengambilan sampling menggunakan purposive sampling dan jumlah subjek 5 balita stunting untuk menguji daya terima PMT pastel tutup. Penelitian ini dilakukan pada tanggal 15-21 September 2020 di Puskesmas Dinoyo dan Kelurahan Ketawanggede. Parameter yang diujikan yaitu organoleptik, perlakuan terbaik, komposisi gizi, mutu protein dan daya terima. Data diolah dengan Microsoft Office Excel 2007. Adapun perlakuan yang diberikan adalah P1 (95\% daging ayam dan 5\% daun kelor) dan P2 (85\% daging ayam dan 15\% daun kelor). Hasil penelitian uji organoleptik mutu hedonik PMT pastel tutup terhadap warna P1 dan P2 memiliki warna kuning pudar, rasa P1 gurih dan P2 sangat gurih, aroma P1 dan P2 kurang beraroma sedap dan langu, tekstur P1 dan P2 agak lembut dan empuk. Hasil uji organoleptik hedonik terhadap warna, rasa, aroma dan tesktur rata-rata panelis menyukai PMT pastel tutup P1 dan P2. Kesimpulannya rata-rata daya terima PMT pastel tutup yaitu 65\% dikarenakan rasa dan tekstur yang kurang disukai oleh balita.
\end{abstract}

Kata kunci: daya terima; mutu protein; nilai cerna; PMT

\section{Chicken and Moringa Oleifera Casserole as Supplementary Feeding Stunted Toddler in Dinoyo Public Health Center Malang City}

\begin{abstract}
Stunting is a growth problem caused by insufficient intake of nutrients for a long time. Casserole as supplementary feeding expected to be able handle stunting. Objective of this study was to examine the characteristics of the nutritional fact, protein quality and acceptance of casserole using Completely Randomized Design. There were 15 semi-trained panelists involved in the organoleptic tests. There were 5 stunted toddlers as the result of purposive sampling that tested to the acceptance of casserole as supplementary feeding. The research was conducted at the Dinoyo Puskesmas, Ketawanggede
\end{abstract}

\footnotetext{
* Corresponding author: fitriakurniawati07@gmail.com

Cite this as: Kurniawati, F., \& Komalyna, I. N. T. (2021). Pastel Tutup Daging Ayam dan Daun Kelor sebagai Pemberian Makanan Tambahan Balita Stunting di Puskesmas Dinoyo Kota Malang: Kajian Nilai Gizi, Mutu Protein dan Daya Terima. AgriHealth: Journal of Agri-food, Nutrition and Public Health, 2(1), 8-16. doi: http://dx.doi.org/10.20961/agrihealth.v2i1.47071
} 
Village, Malang City, from 15 to 21 September 2020. The parameters were organoleptic test, best treatment, nutritional fact and acceptability. The data were analyzed with Microsoft Office Excel 2007. The treatments were P1 (95\% chicken and 5\% Moringa oleifera) and P2 (85\% chicken and 15\% Moringa oleifera). The results of the test organoleptic hedonic showed that P1 and P2 had a faded yellow color, the taste of $P 1$ was savory and P2 was very tasty, the aromas of P1 and P2 were less pleasant and unpleasant, the textures of $P 1$ and $P 2$ were rather soft and tender. The hedonic organoleptic test results showed the color, taste, aroma and texture P1 and P2 in the average of panelists like. The conclusion the average acceptance of casserole as supplementary feeding is 65\% due to the taste and texture that is less liked the toddlers.

Keywords: acceptability; digestibility value; protein quality; supplementary feeding

\section{PENDAHULUAN}

Stunting merupakan rendahnya energi dan protein dalam jangka waktu yang lama ditandai dengan tinggi badan menurut umur yang rendah. Stunting atau "pendek" ialah keadaan gagal tumbuh pada usia bayi (0-11 bulan) serta usia balita (12-59 bulan) yang diakibatkan kurangnya gizi pada 1.000 hari awal kehidupan (Kementerian Kesehatan RI, 2018). Stunting akan berdampak jangka pendek dan panjang pada status kesehatan balita (Hall et al., 2018). Stunting sangat berhubungan dengan tingkat asupan energi balita, berat badan lahir, tingkat pendidikan ibu dan tingkat pendapatan keluarga dengan kejadian stunting pada anak usia 24-59 (Setiawan et al., 2018). Informasi Profil Kesehatan Kota Malang Tahun 2019 balita stunting sebanyak 19,7\% atau 1.640, sedangkan di wilayah kerja Puskesmas Dinoyo bayi stunting tahun 2020 sebanyak 461 bayi serta proporsi bayi stunting di Kelurahan Ketawanggede tahun 2020 sebanyak 19\% (Puskesmas Dinoyo, 2020).

Pemberian Makanan Tambahan (PMT) merupakan salah satu penanganan stunting. PMT akan melengkapi kebutuhan zat gizi, sehingga dapat mencapai berat badan menurut usianya. PMT pada balita bisa berupa mengenalkan produk yang padat gizi dan makanan yang menyehatkan (Damayanti et al., 2019). Salah satu sumber protein yang digunakan yaitu daging ayam merupakan bahan makanan bergizi mudah untuk didapatkan, baunya tidak terlalu amis, sehingga disukai banyak orang terutama pada balita di Ketawanggede. Penambahan daun kelor berfungsi sebagai upaya penanggulangan permasalahan kekurangan gizi pada balita seperti masalah gizi stunting. Dibuktikan dengan hasil penelitian menurut (Irwan et al., 2020) pemberian cookies dari daun dan biji kelor dapat memberikan secara signifikan kenaikan berat badan, sedangkan menurut penelitian (Muliawati et al., 2019) pemberian ekstrak daun kelor secara signifikan dapat meningkatkan tinggi badan balita.

Daun kelor merupakan tanaman yang banyak manfaatnya yang kaya dengan vitamin dan mineral. Daun kelor segar mengandung kalsium $1077 \mathrm{mg}$, zat besi $6 \mathrm{mg}$, protein $5,1 \mathrm{~g}$, zinc 0,6 , vitamin A 6,78 mg, vitamin B1 0,3 mg, vitamin C $22 \mathrm{mg}$ (Kemenkes, 2018). Penelitian yang dilakukan Muliawati et al. (2019) menyatakan bahwa ekstrak daun kelor yang begitu banyak, sangat bermanfaat untuk pertumbuhan dan perkembangan bayi dan balita. Kandungan kalsium yang begitu tinggi dapat menjadikan salah satu cara untuk meningkatkan tinggi badan balita sebesar $0,342 \mathrm{~cm}$ dengan prediksi sebesar 16,2 \%. Penelitian lain dari Rahayu et al. (2018) menyatakan bahwa balita sebelum diberikan ekstrak daun kelor status gizinya kurus dan setelah diberikan ekstrak daun kelor status gizi pada balita naik. Tingginya kandungan nutrisi dari daun kelor menjadikannya sebagai alternatif bahan yang dapat ditambahkan ke berbagai pangan olahan untuk meningkatkan nilai gizi (fortifikasi) (Indriasari et al., 2019).

Rata-rata masyarakat kurang menyukai daun kelor dikarenakan memiliki bau langu, sehingga perlu adanya inovasi dalam mengolah daun kelor menjadi suatu produk yang dapat diterima masyarakat. Dalam hal ini berinovasi pembuatan pengembangan formula berbahan dasar ayam dan penambahan daun kelor dalam bentuk PMT pastel tutup. Memilih PMT berupa pastel tutup dikarenakan bahan-bahan penyusunnya mudah serta cara membuatnya mudah dengan cara dikukus. Pastel tutup daging ayam dan daun kelor adalah makanan selingan sajian klasik berbahan dasar kentang dan isi daging serta sayuran. Tujuan umum dari penelitian ini adalah untuk mengkaji 
karakteristik nilai gizi, mutu protein dan daya terima dari Pastel Tutup sebagai salah satu alternatif pangan fungsional dalam bentuk PMT Pemulihan balita yang padat gizi diperuntukkan bagi balita stunting.

\section{BAHAN DAN METODE}

\section{Waktu dan tempat penelitian}

Penelitian dilakukan di Puskesmas Dinoyo dan Kelurahan Ketawanggede Kota Malang, pada 15 September 2020 sampai dengan 21 September 2020.

\section{Jumlah dan cara pengambilan subjek}

Subjek uji organoleptik 15 panelis agak terlatih yaitu pegawai Puskesmas Dinoyo Kota Malang yang dilatih sebelumnya untuk mengetahui sifat sensorik dengan kriteria inklusif tidak sakit.

Populasi seluruh balita stunting di wilayah Kelurahan Ketawanggede Kota Malang. Teknik pengambilan sampling menggunakan purposive sampling. Tahapan penentuan sampel yaitu balita usia 12-47 bulan yang telah dikunjungi rumahnya untuk pengambilan data awal, selanjutnya diacak untuk mendapatkan panelis yang cocok untuk menerima PMT. Jumlah subjek daya terima 5 balita.

\section{Alat dan bahan}

Alat yang digunakan baskom stainless, timbangan digital, pisau, piring, pengukus, panci, sendok, talenan, mangkuk, aluminium cup foil. Bahan segar daging ayam, daun kelor, kentang, telur ayam ras, wortel, bawang putih dan bawang bombai diperoleh dari pasar besar Malang.

Bahan kering yaitu susu "dancow" produksi PT. Nestle Indonesia, gula pasir "Sania" produksi PT. Duta Sugar Internasional, keju "Meg" produksi PT. Megmilk Snow Brand Indonesia, bihun "Jagung Padamu" produksi PT Sinar Pangan Sejahtera, garam "Cap Kapal" produksi PT. Susanti Megah, margarine "Blue Band" produksi Upfield Manufacturing Indonesia. Alat dan bahan diperoleh dari Kota Malang

\section{Perbandingan komposisi bahan tiap taraf perlakuan pastel tutup}

Penelitian menggunakan desain Rancangan Acak Lengkap terdiri dari satu faktor yaitu daging ayam dan daun kelor dengan 2 perlakuan. P1 (95\% daging ayam dan 5\% daun kelor); P2 (85\% daging ayam dan $15 \%$ daun kelor). Perbandingan dan komposisi bahan bisa dilihat pada Tabel 1.
Tabel 1. Perbandingan komposisi bahan tiap taraf perlakuan

\begin{tabular}{lrr}
\hline \multicolumn{1}{c}{ Bahan $(\mathrm{g})$} & P1 & P2 \\
\hline Ayam & 38 & 34 \\
Daun kelor & 2 & 6 \\
Kentang & 50 & 50 \\
Telur & 5 & 5 \\
Bihun & 5 & 5 \\
Wortel & 5 & 5 \\
Susu & 5 & 5 \\
Keju & 5 & 5 \\
Margarin & 5 & 5 \\
\hline \multicolumn{1}{c}{ Total } & 120 & 120 \\
\hline
\end{tabular}

Sumber: Ellen (2019) dengan modifikasi penulis

\section{Prosedur pengolahan}

Cuci dan cincang ayam, rebus bihun selama 5 menit pada suhu $90^{\circ}-100^{\circ} \mathrm{C}$, blanching daun kelor pada suhu $80^{\circ} \mathrm{C}$ selama 25 detik, kupas dan cuci wortel serta kentang, cincang wortel dan kukus kentang selama 10 menit dengan suhu $80^{\circ}-90^{\circ} \mathrm{C}$. Tumis bawang putih dan bawang bombai menggunakan margarin. Tumis ayam, bihun dan wortel, kemudian tambahkan telur, susu dan daun kelor. Haluskan kentang dan letakkan pada aluminium foil dengan layer 1 sebagai isi dan layer 2 kentang dan keju. Kukus pada suhu $80^{\circ} \mathrm{C}$ selama 20 menit.

\section{Parameter pengamatan}

\section{Uji organoleptik}

Uji hedonik meliputi warna, rasa, aroma dan tekstur dengan penilaian (1) sangat tidak suka, (2) tidak suka, (3) agak suka, (4) suka, (5) sangat suka. Penilaian uji mutu hedonik warna (1) putih, (2) kuning, (3) agak kuning, (4) kuning pudar, (5) kuning agak putih. Penilaian terhadap rasa (1) hambar, (2) kurang gurih, (3) agak gurih, (4) sangat gurih, (5) gurih. Penilaian terhadap aroma (1) langu dan amis, (2) agak langu dan amis, (3) agak sedap dan langu, (4) kurang sedap dan langu, (5) sedap. Penilaian terhadap tekstur (1) sangat lembek, (2) lembek, (3) agak lembek, (4) agak lembut dan empuk (5) lembut dan empuk, kemudian diolah menggunakan Microsoft Office Excel 2007.

2. Komposisi gizi dan mutu protein

Komposisi gizi dihitung menggunakan TKPI 2017 (Tabel Komposisi Gizi Indonesia), sedangkan mutu protein dihitung menggunakan tabel kandungan Asam Amino (AA) esensial bahan makanan. 
3. Perlakuan terbaik

Penentuan perlakuan terbaik menggunakan metode indeks efektivitas yaitu mengelompokkan parameter, memberikan bobot nilai 0-1 pada setiap parameter, menghitung NE (Nilai Efektivitas) dengan rumus:

$$
\mathrm{NE}=\frac{\text { Nilai perlakuan }- \text { Nilai terjelek }}{\text { Nilai terbaik }- \text { Nilai terjelek }}
$$

Setelah menghitung NE lalu hitung NH (Nilai Hasil) dari semua variabel dengan mengalikan NE dengan bobot nilai, kemudian jumlahkan $\mathrm{NH}$. $\mathrm{NH}$ tertinggi adalah perlakuan terbaik.

4. Daya terima

Hasil dari perlakuan terbaik diperoleh takaran saji, kemudian dilakukan daya terima menggunakan form comstock.

\section{HASIL DAN PEMBAHASAN}

\section{Uji organoleptik (mutu hedonik dan hedonik)}

Uji organoleptik adalah uji sensori yang dinilai dengan indra manusia sebagai alat untuk menilai suatu produk. Uji organoleptik terdiri dari uji mutu hedonik dan uji hedonik. Uji mutu hedonik merupakan kesan khas dari produk seperti warna kuning, rasa gurih, tekstur empuk dan aroma amis, sedangkan uji hedonik adalah untuk mengukur tingkat kesukaan (suka, sangat suka, agak suka, tidak suka) terhadap produk (Stone dan Joel, 2004). Berdasarkan Gambar 1 diketahui produk PMT pastel tutup yang dikemas menggunakan aluminium foil, kemudian dilakukan uji organoleptik. Hasil rekapitulasi penilaian uji mutu hedonik dan hedonik oleh 15 panelis semi terlatih dapat dilihat pada Tabel 2 .

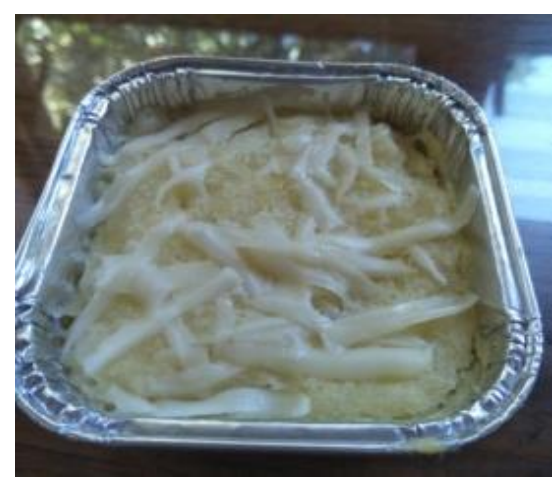

Gambar 1. PMT pastel tutup

Tabel 2. Hasil analisa mutu hedonik pastel tutup daging ayam dan daun kelor

\begin{tabular}{lcccc}
\hline \multirow{2}{*}{ Parameter } & Perlakuan 1 & \multicolumn{3}{c}{ Perlakuan 2 } \\
\cline { 2 - 5 } & Mutu hedonik & Hedonik & Mutu hedonik & Hedonik \\
\hline Warna & Kuning pudar & Suka & Kuning pudar & Suka \\
Rasa & Gurih & Suka & Sangat gurih & Suka \\
Aroma & Kurang beraroma sedap dan langu & Suka & Kurang beraroma sedap dan langu & Suka \\
Tekstur & Agak lembut dan empuk & Suka & Agak lembut dan empuk & Suka \\
\hline
\end{tabular}

1. Warna

Pada Tabel 2 diketahui perlakuan P1 (ayam 95\% dan kelor 5\%) memiliki rata-rata sebesar 3,9 dengan kriteria kuning pudar dan perlakuan P2 (85\% dan kelor 10\%) memiliki rata-rata sebesar 4,2 dengan kriteria kuning pudar, sedangkan hasil rekapitulasi penilaian uji hedonik perlakuan 1 memiliki rata-rata sebesar 3,5 dengan kategori suka dan perlakuan 2 memiliki rata-rata sebesar 3,8 dengan kategori suka.

Produk pastel tutup terdiri dari 2 lapisan, lapisan ke dua yaitu isi dari pastel tutup terdiri dari ayam, kelor, bihun dan telur. Lapisan pertama terdiri dari kentang dan keju, sehingga penampakan pastel tutup berwarna kuning pudar. Dalam pembuatan pastel tutup kentang yang digunakan yakni kentang kuning atau disebut dengan kentang granola. Memilih kentang kuning dikarenakan disukai oleh masyarakat, memiliki karakteristik tidak lembek, bertekstur lembut serta tidak mudah hancur, selain itu memiliki rasa yang enak dan gurih. Kentang kuning memiliki bentuk oval dan salah satu jenis variasi kentang yang unggul serta produktivitasnya tinggi (Purnomo et al., 2017).

2. Rasa

Pada Tabel 2 diketahui perlakuan 1 (ayam 95\% dan kelor 5\%) memiliki rata-rata sebesar 4,5 dengan kriteria gurih dan perlakuan 2 (85\% dan kelor $10 \%)$ memiliki rata-rata sebesar 3,7 dengan kriteria sangat gurih, sedangkan hasil rekapitulasi penilaian uji hedonik perlakuan 1 memiliki rata-rata 
sebesar 4 dengan kategori suka dan perlakuan 2 memiliki rata-rata sebesar 3,6 dengan kategori suka. Penambahan daun kelor yang sedikit mempengaruhi tingkat kesukaan panelis terhadap parameter rasa. Hal tersebut sejalan dengan penelitian Evivie et al. (2016) yang menyatakan bahwa penambahan daun kelor yang lebih banyak akan mempengaruhi daya terima rasa produk, dikarenakan terdapat tanin pada daun kelor yang menyebabkan rasa sepat. Akibat penggumpalan protein yang menyelimuti rongga mulut serta lidah, sehingga memunculkan rasa sepat, tetapi pada pastel tutup ini, rasa dari daun kelornya sendiri tidak begitu dominan sehingga tidak terasa sepat karena hanya penambahan $5-10 \%$.

3. Aroma

Pada Tabel 2 diketahui perlakuan 1 (ayam 95\% dan kelor 5\%) memiliki rata-rata sebesar 4,2 dengan kriteria kurang beraroma sedap dan langu perlakuan 2 ( $85 \%$ dan kelor $10 \%$ ) memiliki rata-rata sebesar 3,9 dengan kriteria kurang beraroma sedap dan langu, sedangkan hasil rekapitulasi penilaian uji hedonik pada perlakuan 1 memiliki rata-rata sebesar 3,6 dengan kategori suka dan perlakuan 2 memiliki rata-rata sebesar 3,7 dengan kategori suka.

Daun kelor memiliki aroma yang langu dan hasil dari uji organoleptik menunjukkan PMT pastel tutup kurang beraroma langu hal tersebut dikarenakan pada pembuatan pastel tutup, mem-blanching daun kelor terlebih dahulu selama 25 detik, dikarenakan untuk menghindari aroma langu yang dihasilkan dari daun kelor. Hal tersebut sejalan dengan penelitian menurut Shuntang (2018) aroma langu disebabkan oleh beberapa komponen metabolit sekunder yang ada pada daun kelor yaitu saponin, tannin dan asam pitat, tetapi dapat diminimalisir dengan cara blanching (celup cepat). Selain itu, untuk menghindari aroma langu dari daun kelor bisa menggunakan cara memetik daun kelor, lalu mencuci bersih dan menyimpan pada suhu ruang $30^{\circ} \mathrm{C}$ sampai $32^{\circ} \mathrm{C}$ (Rosyidah dan Ismawati, 2016).

4. Tekstur

Pada Tabel 2 diketahui perlakuan 1 (ayam 95\% dan kelor 5\%) memiliki rata-rata sebesar 3,9 dengan kriteria agak lembut dan empuk perlakuan $2(85 \%$ dan kelor $10 \%)$ memiliki rata-rata sebesar 4 dengan kriteria agak lembut dan empuk, sedangkan hasil rekapitulasi penilaian uji hedonik pada perlakuan 1 memiliki rata-rata sebesar 4,1 dengan kategori suka dan perlakuan 2 memiliki rata-rata sebesar 4 dengan kategori suka.

Tabel 2 menunjukkan bahwa hasil uji organoleptik tekstur pastel tutup yang dihasilkan yakni agak lembut dan empuk. Pada saat uji organoleptik tekstur dari P1 (95\% ayam dan $5 \%$ kelor) yakni lapisan kedua terdiri dari isi pastel tutup sedikit berair, hal tersebut dikarenakan pengaruh dari proporsi penambahan kelor hanya 5\%, karena menurut Tofu dan Leaf (2016) daun kelor mengandung serat 5 kali lebih banyak dari pada sayur pada umumnya. Fungsi serat yakni dapat menyerap air secara cepat serta mengakibatkan tekstur dari suatu produk pangan menjadi cepat rapuh, sehingga dapat disimpulkan bahwa dengan penambahan kelor semakin sedikit kemampuan dalam menyerap air juga rendah dan dapat mempengaruhi tekstur sebuah produk.

\section{Perlakuan terbaik}

Perlakuan terbaik ditentukan dengan mempertimbangkan beberapa variabel yang dianggap penting pada mutu PMT pastel tutup. Peranan tiap variabel diperoleh dengan pemberian bobot pada masing-masing variabel yang dilakukan oleh panelis. Rangking pertama yaitu merupakan variabel terpenting pada mutu PMT pastel tutup yaitu rasa, rangking kedua aroma, rangking ketiga warna dan rangking keempat tekstur. Perlakuan terbaik dapat ditentukan melalui perhitungan indeks efektivitas, dengan cara menentukan nilai terbaik dan nilai terjelek dari masing-masing variabel dari setiap perlakuan. Sehingga, didapatkan satu produk dengan perlakuan terbaik. Nilai hasil perhitungan masing-masing perlakuan dapat dilihat dari Tabel 3.

\section{Tabel 3. Penentuan perlakuan terbaik}

\begin{tabular}{lcc}
\hline \multicolumn{1}{c}{ Perlakuan } & $\mathrm{P} 1$ & $\mathrm{P} 2$ \\
\hline Jumlah nilai hasil & $3,32^{*}$ & 0,48 \\
Peringkat & $\mathrm{I}$ & II \\
\hline
\end{tabular}

Keterangan: * = Perlakuan terbaik

Perlakuan dengan nilai hasil tertinggi dianggap sebagai perlakuan terbaik. Perlakuan terbaik didapatkan dari taraf perlakuan 1 (90\% daging 
ayam dan 5\% daun kelor), selanjutnya untuk mengetahui komposisi nilai gizi yang dihitung menggunakan TKPI 2017 dan mutu protein yang dihitung menggunakan tabel kandungan Asam Amino (AA) esensial bahan makanan PMT pastel tutup per 120 g. Komposisi gizi dapat dilihat pada Tabel 4.

\section{Takaran saji PMT pastel tutup daging ayam dan daun kelor}

Takaran saji pastel tutup dengan penambahan daun kelor bertujuan menambah asupan energi, protein, zat besi dan zinc yang diberikan berupa PMT selingan 2 kali makan dalam sehari, sehingga menyumbangkan $20 \%$ energi untuk kebutuhan energi dalam sehari. Takaran saji pastel tutup dapat dilihat pada Tabel 5 .
Tabel 4. Komposisi gizi pastel tutup perlakuan 1 (90\% daging ayam dan 5\% daun kelor) per $120 \mathrm{~g}$

\begin{tabular}{lc}
\hline \multicolumn{1}{c}{ Komposisi } & Nilai \\
\hline Energi & $243,13 \mathrm{kkal}$ \\
Protein & $10,958 \mathrm{~g}$ \\
Lemak & $10,322 \mathrm{~g}$ \\
Karbohidrat & $14,846 \mathrm{~g}$ \\
Fe & $1,435 \mathrm{mg}$ \\
Zinc & $0,645 \mathrm{mg}$ \\
Mutu cerna & $92,90 \%$ \\
NPU & $56,38 \%$ \\
PST & $80,31 \%$ \\
PER & $132,13 \%$ \\
\hline
\end{tabular}

Sumber : TKPI (2017) dan Tabel Kandungan Asam Amino (AA) Esensial Bahan Makanan

Tabel 5. Informasi nilai gizi pastel tutup

\begin{tabular}{lcc}
\hline \multicolumn{2}{c}{ Informasi nilai gizi/nutrition facts } \\
\hline Takaran saji & $60 \mathrm{~g}$ \\
Jumlah sajian per kemasan & 1 \\
Berat Perkemasan & $60 \mathrm{~g}$ \\
Energi total & $122 \mathrm{kkal}$ \\
& & $\% \mathrm{AKG}^{*}$ \\
Protein & Jumlah per sajian & $27,40 \%$ \\
Lemak total & $5,48 \mathrm{~g}$ & $17,00 \%$ \\
Karbohidrat & $7,66 \mathrm{~g}$ & $3,50 \%$ \\
Besi & $7,42 \mathrm{~g}$ & $10,25 \%$ \\
Seng & $0,72 \mathrm{mg}$ & $10,75 \%$ \\
\hline
\end{tabular}

Keterangan: * = Persen AKG berdasarkan kebutuhan energi 1.350 kkal. Kebutuhan energi anda mungkin lebih tinggi atau lebih rendah

Pada Tabel 5, menyajikan tentang informasi nilai gizi per sajian pastel tutup berdasarkan kebutuhan energi balita usia 12-47 bulan menurut AKG (2019). Konsumsi pastel tutup berdasarkan takaran saji per sekali makan yaitu 1 cup aluminium foil berukuran kecil dengan berat $60 \mathrm{~g}$ memperoleh energi sebesar $122 \mathrm{kkal}$, protein 5,48 $\mathrm{g}$, lemak 7,66 g, karbohidrat 7,42 g, zat besi 0,72 $\mathrm{mg}$ dan zinc $0,32 \mathrm{mg}$ yang dapat memenuhi $10 \%$ kebutuhan energi dalam sekali makan PMT.

Standar PMT balita tiap $100 \mathrm{~g}$ atau satu bungkus biskuit yang terdiri dari 12 keping mengandung energi sebesar $540 \mathrm{kkal}$, protein $9 \mathrm{~g}$, lemak $14 \mathrm{~g}$ dan karbohidrat $71 \mathrm{~g}$, jika dibandingkan dengan pastel tutup daging ayam dan daun kelor per $100 \mathrm{~g}$ mengandung energi sebesar 203,33 kkal, protein 9,1 g, lemak 12,7 g, karbohidrat $12,36 \mathrm{~g}$, zat besi 1,2 mg dan zinc 0,53 mg. Dari segi energinya masih unggul standar PMT biskuit, tetapi pada protein sudah memenuhi dari standar PMT. Pastel tutup memiliki keunggulan dari kandungan zat mikro yaitu zat besi dan zinc yang berpengaruh terhadap balita stunting, selain itu daya cerna protein tinggi pada PMT pastel tutup sebesar 92\%. Bahan-bahan penyusun pembuatan pastel tutup yaitu dari protein hewani seperti ayam dan telur yang mengandung asam amino esensial lengkap dan merupakan protein yang bernilai biologis tinggi. Asam amino protein nabati didapatkan dari daun kelor. Mutu cerna protein hewani lebih tinggi dari pada protein nabati (Tessema et al., 2018). Keuggulan lainnya dari PMT pastel tutup daging ayam dan daun kelor yakni nilai NPU, PST dan PER yang tinggi dapat dilihat pada Tabel 5. NPU (Net Protein Utilization) bagian protein yang dapat dimanfaatkan oleh tubuh. PST (Protein Sel Tunggal) artinya mengandung kadar protein tunggal, sedangkan PER (Protein Efficiency Ratio) adalah bagian protein yang 
digunakan sebagai pembentuk energi. Dalam penyajian pastel tutup dengan aluminium cup foil ukuran kecil, dikemas dengan mika plastik dilengkapi sendok dan direkatkan menggunakan isolasi. Penggunaan staples diusahakan sedikit mungkin karena rentan terhadap keamanan pangan karena sasaran adalah balita.

\section{Daya terima PMT pastel tutup daging ayam dan daun kelor}

Daya terima PMT pastel tutup (ayam 95\% dan kelor 5\%) pada 5 balita stunting usia 12-47 bulan terhadap yaitu memiliki rata-rata $65 \%$. Daya terima PMT pastel tutup dapat dilihat pada Tabel 6.

Tabel 6. Daya terima PMT pastel tutup

\begin{tabular}{cc}
\hline Balita & Daya terima $(\%)$ \\
\hline 1 & $100 \%$ \\
2 & $50 \%$ \\
3 & $75 \%$ \\
4 & $75 \%$ \\
5 & $25 \%$ \\
\hline
\end{tabular}

Pada balita 2 dan 5 daya terimanya paling rendah dikarenakan balita sulit makan. Balita 2 sulit makan karena ibu balita terbiasa memberikan susu formula sebelum makan. Hal tersebut akan berpengaruh pada balita terkait pengenalan dan kesukaan terhadap makanan, karena orang tua tidak membiasakan mengenalkan makanannya secara telaten dan sabar. Hal tersebut sejalan dengan yang dikatakan oleh Nafadza et al. (2019) bahwa praktik pemberian makanan pada balita yang tidak tepat akan berpengaruh terhadap status gizi, daya terima dan kesukaan balita pada suatu makanan, selain itu balita 2 tidak menyukai rasa dari isi pastel tutup. Isi pastel tutup terdiri dari ayam, daun kelor, bihun dan wortel yang di cincang halus. Faktor-faktor tersebut akan berpengaruh terhadap daya terima pastel tutup.

Pada balita 5 mengalami tumbuh gigi, sehingga nafsu makan balita tersebut menurun. Balita mengeluarkan banyak air liur menandakan gigi seri tumbuh, akan memperlihatkan suka menggigit karena gusi terasa gatal, akibat kondisi yang kurang nyaman dari balita tersebut akan kehilangan nafsu makan pada balita (Fatmawati, 2012). Balita 5 tidak menyukai dari isi tekstur pastel tutup karena pada isi pastel tutup agak kasar karena terdapat ayam, daun kelor, bihun dan wortel yang di cincang halus. Faktor-faktor tersebut akan berpengaruh terhadap daya terima pastel tutup.

Daya terima terhadap menu makanan, terdiri dari penilaian sensori yang akan mempengaruhi dari jumlah makanan yang dikonsumsi anak dikarenakan nantinya akan berpengaruh terhadap konsumsi energi dan zat gizi pada balita, sehingga PMT pastel tutup ini memberikan kontribusi terhadap konsumsi energi dan zat gizi total pada balita.

Berdasarkan Tabel 7 dapat diketahui bahwa sisa makanan yang terlalu tinggi atau makanan yang dikonsumsi semakin sedikit akan mempengaruhi kebutuhan zat gizi balita semakin tidak terpenuhi, sedangkan balita 1 yang tidak meninggalkan sisa pada produk PMT pastel tutup akan menyumbang $10 \%$ dari total kebutuhan balita usia 12-47 bulan. Daya terima yang rendah dikarenakan rasa dan tekstur kurang disukai pada balita 2 dan 5 .

Tabel 7. Kandungan gizi menurut daya terima balita

\begin{tabular}{cccccccc}
\hline Balita & Daya terima & Energi (kkal) & Protein $(\mathrm{g})$ & Lemak $(\mathrm{g})$ & $\mathrm{KH}(\mathrm{g})$ & Zat besi $(\mathrm{mg})$ & Zinc $(\mathrm{mg})$ \\
\hline 1 & $100 \%$ & 122,0 & 5,48 & 4,66 & 7,42 & 0,72 & 0,32 \\
3 dan 4 & $75 \%$ & 91,5 & 4,11 & 5,75 & 5,57 & 0,54 & 0,24 \\
2 & $50 \%$ & 61,0 & 2,74 & 2,33 & 3,71 & 0,36 & 0,16 \\
5 & $25 \%$ & 30,5 & 1,37 & 0,58 & 0,93 & 0,09 & 0,08 \\
\hline
\end{tabular}

Sumber: TKPI (2017)

\section{KESIMPULAN}

Terdapat 2 perlakuan dalam pembuatan pastel tutup P1 (90\% daging ayam dan 5\% daun kelor) dan $\mathrm{P} 2$ (85\% daging ayam dan $15 \%$ daun kelor). Perlakuan terbaik (P1) yang disukai panelis warna kuning pudar, rasa gurih, aroma kurang sedap dan langu, tekstur agak lembut dan empuk, mutu cerna 92,9\%, NPU 56,38\%, PST 80,31\%, PER 132,13\%, rata-rata daya terima PMT $65 \%$ dikarenakan rasa dan tekstur yang kurang disukai oleh balita. Sebaiknya perlu adanya pengembangan lebih lanjut terhadap formulasi dengan memodifikasi bahan pangan lokal lain agar dapat meningkatkan daya terima PMT dan 
diharapkan untuk melakukan laboratorium analisis kandungan zat gizi.

\section{UCAPAN TERIMA KASIH}

Ucapan terima kasih penulis sampaikan kepada ibu balita serta balita di Kelurahan Ketawanggede dan pegawai Puskesmas Dinoyo Kota Malang yang telah membantu dalam penelitian ini.

\section{DAFTAR PUSTAKA}

Damayanti, L. D., Suwena, K. R., \& Haris, I. A. (2019). Analisis kepuasan masyarakat terhadap pelayanan publik berdasarkan Indeks Kepuasan Masyarakat (IKM) Kantor Kecamatan Sawan Kabupaten Buleleng. Jurnal Pendidikan Ekonomi Undiksha, 11 (1), 21-32. https://doi.org/10.23887/jjpe.v11 i1.20048

Evivie, S., Ebabhamiegbebho, P., Imaren, J., \& Igene, J. (2016). Evaluating the organoleptic properties of soy meatballs (BEEF) with varying levels of Moringa oleifera leaves powder. Journal of Applied Sciences and Environmental Management, 19(4), 649-656. https://doi.org/10.4314/jasem.v19i4.12

Fatmawati, H. (2012). Gigi, pintu gerbang kesehatan buah hati kita. dalam Jendela Husada Edisi 3. Sleman: Dinas Kesehatan Kabupaten Sleman. Tersedia dari https:// dinkes.slemankab.go.id/wp-content/uploads/ 2013/07/hal-11-13-gigi-anak.pdf

Hall, C., Bennett, C., Crookston, B., Dearden, K., Hasan, M., Linehan, M., Syafiq, A., Torres, S., \& West, J. (2018). Maternal knowledge of stunting in rural Indonesia. International Journal of Child Health and Nutrition, 7(4), 139-145. https://doi.org/10.6000/1929-4247. 2018.07.04.2

Indriasari, Y., Basrin, F., \& Salam, M. (2019). Analisis penerimaan konsumen Moringa Biscuit (biskuit kelor) diperkaya tepung daun kelor (Moringa oleifera). Agroland: Jurnal Ilmu-Ilmu Pertanian, 26(3), 221229. https://core.ac.uk/download/pdf/296928 689.pdf

Irwan, Z., Salim, A., \& Adam, A. (2020). Pemberian cookies tepung daun dan biji kelor terhadap berat badan dan status gizi anak balita di wilayah kerja Puskesmas Tampa Padang. AcTion: Aceh Nutrition Journal, 5(1), 45-54. https://doi.org/10.30867/action.v5i1.198

Kemenkes RI. (2018). Tabel komposisi pangan Indonesia. Jakarta: Kemenkes RI.

Kementerian Kesehatan RI. (2018). Buku saku pemantauan status gizi. Buku Saku Pemantauan Status Gizi Tahun 2017, 7-11.

Muliawati, D., Sulistyawati, N., \& Utami, F. S. (2019). Manfaat ekstrak Moringa oleifera terhadap peningkatan tinggi badan balita. Prosiding Seminar Nasional: Pertemuan Ilmiah Tahunan Politeknik Kesehatan Karya Husada Yogyakarta, 1(1), 46-55. Tersedia dari http://jurnal.poltekkeskhjogja.ac.id/index .php/PSN/article/view/371

Nafadza, R. F., Buanasita, A., \& Nindya, T. S. (2019). Perbedaan praktik pemberian makan dan status ketahanan pangan rumah tangga pada balita status gizi kurang dan normal. Amerta Nutrition, 3(1), 63-70. https://doi. org/10.2473/amnt.v3i1.2019.63-70

Purnomo, E., Suedy, S. W. A., \& Haryanti, S. (2017). Pengaruh cara dan waktu penyimpanan terhadap susut bobot, kadar glukosa dan kadar karotenoid umbi kentang konsumsi (Solanum tuberosum L. Var Granola). Buletin Anatomi Dan Fisiologi, 2(2), 107-113. https://doi.org/10.14710/baf. 2.2.2017.107-113

Rahayu, T. B., Anna, Y., \& Nurindahsari, W. (2018). Peningkatan status gizi balita melalui pemberian daun kelor (Moringa Oleifera). Jurnal Kesehatan Madani Medika, 9(2), 8791. https://doi.org/10.36569/jmm.v9i2.14

Rosyidah, A. Z., \& Ismawati, R. (2016). Studi tentang tingkat kesukaan responden terhadap penganekaragaman lauk pauk dari daun kelor (Moringa oleivera). Jurnal Online Tata Boga, 5(1), 17-22. Tersedia dari https://jurnalmahasiswa.unesa.ac.id/index.php /jurnal-tata-boga/article/view/13427

Setiawan, E., Machmud, R., \& Masrul, M. (2018). Faktor-faktor yang berhubungan dengan kejadian stunting pada anak usia 24-59 bulan di wilayah kerja Puskesmas Andalas Kecamatan Padang Timur Kota Padang Tahun 2018. Jurnal Kesehatan Andalas, 7(2), 275284. https://doi.org/10.25077/jka.v7.i2.p275- 
284.2018

Shuntang, G. (2018). Current topics in saponins and the bitter taste. Research in Medical \& Engineering Sciences, 5(1), 390-391. https:// doi.org/10.31031/rmes.2018.05.000601

Tessema, M., Gunaratna, N. S., Brouwer, I. D., Donato, K., Cohen, J. L., Mcconnell, M., Belachew, T., Belayneh, D., \& de Groote, H. (2018). Associations among high-quality protein and energy intake, serum transthyretin, serum amino acids and linear growth of children in Ethiopia. Nutrients, 10(11), 1776. https://doi.org/10.3390/nu10111776

Tofu, A., \& Leaf, M. (2016). Aplikasi tahu dan daun kelor (Moringa oleifera) pada nugget. Media Ilmiah Teknologi Pangan, 3(2), 125-134. Tersedia dari https://scholar. google.co.id/scholar?q=Aplikasi+tahu+dan $+\mathrm{d}$ aun+kelor+(Moringa+oleifera)+pada+nugget. $+\&$ hl $=$ id 